\title{
Making HIV clinic appointments for clients with positive HIV results at testing sites can improve referral rates
}

\author{
Bartosz Szetela ${ }^{1, A-F}$, Łukasz Łapiński2, B-F, Jacek Gasiorowski ${ }^{1, C-F}$, Brygida Knysz ${ }^{3, E, F}$ \\ 1 Independent Laboratory for Monitoring Infections among Drug Users at the Department of Infectious Diseases, Liver Disease and Acquired Immune Deficiencies, \\ Wroclaw Medical University, Poland \\ 2 Department of Clinical Pharmacology, Wroclaw Medical University, Poland \\ ${ }^{3}$ Department of Infectious Diseases, Liver Disease and Acquired Immune Deficiencies, Wroclaw Medical University, Poland \\ A - research concept and design; B - collection and/or assembly of data; C - data analysis and interpretation; \\ $D$ - writing the article; $E$ - critical revision of the article; $F$ - final approval of the article
}

\section{Address for correspondence \\ Bartosz Szetela}

E-mail: bartekszetela@poczta.fm

\section{Funding sources}

None declared

\section{Conflict of interest}

None declared

Received on December 19, 2016

Reviewed on January 15, 2017

Accepted on May 15, 2018

Published online on October 31, 2018

\begin{abstract}
Background. The percentage of people living with undiagnosed HIV infection remains very high in Poland and exceeds $50 \%$ - one of the highest rates in Europe. At the same time, the number of HIV tests performed by medical doctors per 1,000 inhabitants is the lowest in Europe. Thus, every effort should be made to keep diagnosed patients in care. However, a number of patients are lost to care (LTC), with the percentage depending on the testing modality used (voluntary counseling and testing sites - VCTs, private laboratories, medical clinics, clubs) and communication skills of persons giving the results. Until now, there was only 1 prospective study in Poland that looked into the problem of continuum of care.

Objectives. The objective of the study was to assess VCT clients' willingness to accept help with making the first appointment at a local HIV clinic after receiving positive results and the percentage of patients getting into care at the clinic after referral.

Material and methods. Referral efficacy analysis between 2010 and 2014 was a joint venture between VCT site and the largest HIV clinic in Wrocław. Every patient diagnosed with HIV infection was offered personal help with making the first appointment at the HIV clinic. Later, it was assessed whether the first visit actually took place.
\end{abstract}

Results. All the patients who collected their positive results came for their first visit at the HIV clinic with a referral rate reaching $100 \%$, falling to $97.1 \%$ only in 2013 . Most visits took place during 1-2 weeks.

Conclusions. Patients were willing to use counselors' help with making appointments at the HIV clinic, which in turn increased referral rates and numbers of patients retained in care.

Key words: HIV, point of care testing, linkage to care, referral rate, voluntary counseling and testing sites

Cite as

Szetela B, Łapiński Ł, Gasiorowski J, Knysz B. Making HIV clinic appointments for clients with positive HIV results at testing sites can improve referral rates. Adv Clin Exp Med. 2019:28(1):121-124. doi:10.17219/acem/91064

DOI

10.17219/acem/91064

Copyright

Copyright by Author(s)

This is an article distributed under the terms of the

Creative Commons Attribution Non-Commercial License

(http://creativecommons.org/licenses/by-nc-nd/4.0/) 


\section{Introduction}

The percentage of people living with undiagnosed HIV infection remains very high in Poland and exceeds 50\% one of the highest rates in Europe. ${ }^{1}$ Efforts are undertaken to increase HIV testing and coverage among both medical professionals and patients. However, at the same time, people living with diagnosed HIV infection are lost to care due to psychological trauma and feelings of guilt not alleviated when collecting positive HIV results or at any later occasion. ${ }^{2}$ This, in turn, often leads to delayed linkage to care and lost treatment opportunities as well as to continued spread of HIV. ${ }^{3-8}$

As an organization running a voluntary counseling and testing site (VCT) in Wrocław (southwest Poland), we decided to modify the post-test visit for clients obtaining positive results. Commonly, clients who are given positive results are offered counseling and given phone numbers and/or addresses of relevant HIV clinics. It is up to them to make the appointment. As this step may be difficult, the VCT staff decided to offer help with making the necessary appointments already during the post-test visit.

The aim of the study was to observe if such help was accepted and, as a proof-of-concept, if it led to better linkage to care.

\section{Material and methods}

Between 2010 and 2014, we followed 14,371 patients at a VCT site for HIV in Wrocław, Poland (Wszystkich Świętych Street), run by "Podwale Siedem" society (Stowarzyszenie Na Rzecz Osób Wykluczonych i Zagrożonych Wykluczeniem Społecznym "Podwale Siedem") - a nongovernmental organization (NGO). The patients lived mostly in Wrocław and in nearby cities and were between 20 and 40 years of age. Two thirds of them decided to take the HIV test due to heterosexual and $1 / 3$ due to homosexual exposures. All 221 patients who received positive results were referred to a co-located HIV clinic for care and treatment. All new patients at the clinic were crossreferenced to the point of origin of their HIV test results, either the local VCT site or a different external site, allowing us to measure the referral rate of the VCT site (Table 1).
For the efficacy assessment, a joint venture was created with the $2^{\text {nd }}$ largest HIV clinic in Poland, which takes care of 1000 HIV-infected patients and is also located in Wrocław. Knowing how cost-ineffective and epidemiologically damaging losing diagnosed patients is already at the stage of designing the VCT site, we addressed this issue. The VCT site was located in the same building as the HIV clinic. However, the VCT site and the clinic are separated and have different entrances. This arrangement was and still is unique for Polish testing sites. Such proximity and full cooperation between these 2 entities was supposed to allow smooth patient referral. After confirming HIV infection, the importance of immediate medical care was explained to each patient, who, with his/her approval, was referred to the HIV clinic. Counselors made appointments according to patients' wishes and psychological support was offered at the clinic as needed. Patients received notes with the date and time of the visit at the clinic.

Apart from HIV laboratory and rapid tests (free of charge), the full spectrum of sexually transmitted infections (STI) tests was offered (syphilis rapid and laboratory tests free of charge; gonorrhea and chlamydia - partial charge) as well as hepatitis B and C tests (full charge). This was made possible thanks to close cooperation between the NGO and the HIV clinic. Otherwise such a wide range of STI tests would be impossible for any NGO due to strict Polish law (concerning infection control and access to medical procedures).

Descriptive statistics included a number of HIV tests performed in the analyzed period, number of positive results, number of uncollected results, number of referrals, number of actual HIV clinic visits, as well as referral rate, i.e., percentage of HIV-positive patients who came for the first visit after referral (calculated for collected results only and for all positive results).

The data was collected and analyzed with Microsoft Excel 2008 for Mac, v. 12.3.6 (Microsoft Corp., Armonk, USA).

Bioethics Committee opinion was not necessary for this study.

\section{Results}

Between 2010 and 2014, 14,371 patients were tested for HIV and received 251 positive results (prevalence: 1.74\%). Thirty patients did not collect their positive results.

Table 1. Human immunodeficiency virus (HIV) test results and referral rates at the voluntary counseling and testing site in Wrocław between 2010 and 2014

\begin{tabular}{|l|c|c|c|c|c|c|c|}
\hline Year & $\begin{array}{c}\text { HIV tests } \\
\text { performed }\end{array}$ & $\begin{array}{c}\text { Positive HIV } \\
\text { results }\end{array}$ & $\begin{array}{c}\text { Uncollected } \\
\text { results }\end{array}$ & $\begin{array}{c}\text { Referrals } \\
\text { Actual HIV clinic } \\
\text { visits }\end{array}$ & $\begin{array}{c}\text { Referral rate } \\
\text { (collected results } \\
\text { only) [\%] }\end{array}$ \\
\hline 2010 & 2,309 & 38 & 4 & 34 & 34 & 100 \\
(all positive \\
results) [\%]
\end{tabular}


Out of 221 referrals, we confirmed 219 HIV clinic visits, which represents a $99 \%$ referral rate. Specific yearly results are shown in Table 1.

During the 5-year period, among patients who obtained positive results, only 2 refused to make the appointment during the post-test visit. One patient wanted to go to his hometown for further treatment and care, while the other required more time to think about his future. Eventually, the $2^{\text {nd }}$ patient came back to make the appointment on his own.

Most patients came for their visits within 1-2 weeks after diagnosis, although we did not measure this time prospectively. Moreover, each year we managed to diagnose from 1 to 4 acute retroviral infections before seroconversion (1.5-10\% of all diagnosed infections), a situation also vital to reduction of HIV spread. ${ }^{6-7}$

Most HIV infections were diagnosed among men who have sex with men (50-65\%, depending on the year), the $2^{\text {nd }}$ most common cause being heterosexual transmission (30-35\%), with intravenous drug use accounting for not more than $4-8 \%$ of newly diagnosed infections.

\section{Discussion}

Voluntary counseling and testing site remains one of the most important HIV testing modalities in Poland and should be available for persons taking risky behavior, who are often unwilling to use medical clinics. ${ }^{9}$ Negative attitudes toward people reporting risky behavior may be especially harmful and are often seen in medical settings and among medical workers not used to such patients. ${ }^{10-12}$ Although different venues have been created to increase HIV testing (VCT centers, medical clinics, checkpoints, club testing, home sampling, home testing), no diagnosed individual should be left without referral to HIV clinics, where proper medical care and treatment can be offered. Proper linkage to care helps to achieve both individual and epidemiological goals of reducing the HIV burden and increasing fund efficacy.

Ankiersztejn-Bartczak et al. in their TAK project, observed a high percentage of HIV-positive VCT clients lost to care (LTC) $-42 \%$ in Warszawa, Poland. This happened despite universal adoption of proactive linkage procedures by Polish VCT centers. ${ }^{13}$ Such high number of persons LTC necessitates rapid improvement so that neither funds nor lives are lost despite timely diagnosis.

On the other hand, a checkpoint in Barcelona, Spain, achieved a very high referral rate of $90.5 \%$ by employing the same technique as we did in this project (making appointments with the client's approval), regardless of the distance of the site from HIV clinics. ${ }^{14}$ Torian et al. in New York, USA, have shown that collocation of VCT sites and medical clinics allows referral rates to be increased substantially. ${ }^{3}$
Current HIV epidemiology, especially among men who have sex with men, shows that knowing one's HIV status is not enough to change behavior. ${ }^{15-18}$ International and national guidelines for starting HIV therapy almost universally advocate early combined antiretroviral therapy (cART) commencement. Early therapy is said to be beneficial both for patients and for the epidemiological situation (reduction of the population viral load). After recent results of the Strategic Timing of Antiretroviral Treatment (START) trial, early therapy may become even more important for HIV-infected individuals. Hence, both early diagnosis and quick referral and antiretroviral therapy are paramount to reduce HIV spread or even stop the epidemic.

Polish AIDS Scientific Society advocates that all patients receiving positive HIV results should also receive adequate linkage to care. This means either making appointments in HIV clinics with the patient's approval or at least distributing the phone number and address of the nearest clinic. Higher linkage to care can be achieved if the patients are made aware of the importance of early treatment for their own and their relatives' health.

\section{Conclusions}

Patients were willing to use counselors' help with making appointments at the HIV clinic, which in turn increased referral rates and numbers of patients retained in care. This may further lead to a higher percentage of patients with undetectable viraemia.

We recommend that more VCT sites be located near HIV clinics or co-located, not only to improve referral rates but also to allow easy access to professional medical knowledge. If such location is impossible, very close ties between VCT centers and medical clinics are necessary. We also advise that the referral rates of the VCT sites be checked regularly to achieve and sustain high efficacy and cost-effectiveness.

This has been a proof-of-concept study, and it does not obviate the need for varied modalities in HIV testing (clinics, VCT centers, checkpoints, clubs) to cater for special needs of different groups of patients and allow easy access to testing.

\section{Limitations}

Positive and nonjudgmental counseling attitudes at the analyzed VCT site and patients getting to know the clinic and its surroundings before the first visit may have positively impacted referral rates. This may have been the major confounding factor, even though all counselors at Polish VCT sites are educated centrally and are supposed to work under the same guidelines.

Additionally, almost all counselors were medical doctors or had a medical background, which may have favored medicalization attitudes among staff and confounded the results. 


\section{References}

1. Hamers FF, Phillips AN. Diagnosed and undiagnosed HIV-infected populations in Europe. HIV Med. 2008;9(Suppl 2):6-12.

2. Rogowska-Szadkowska D, Chlabicz S, Gasiorowski J, ZubkiewiczZarębska A, Knysz B. Experience of Polish patients diagnosed with HIV before and after highly active antiretroviral therapy (HAART) availability. HIV \& AIDS Review. 2013;12(1):9-13.

3. Torian LV, Wiewel EW, Liu KL, Sackoff JE, Frieden TR. Risk factors for delayed initiation of medical care after diagnosis of human immunodeficiency virus. Arch Intern Med. 2008;168(11):1181-1187.

4. Eichler MR, Ray SM, del Rio C. The effectiveness of HIV post-test counseling in determining healthcare-seeking behavior. AIDS. 2002;16(6): 943-945.

5. Samet JM, Freedberg KA, Stein MD, et al. Trillion virion delay: Time from testing positive for HIV to presentation for primary care. Arch Intern Med. 1998;158(7):734-740.

6. Cohen MS, Chen YQ, McCauley M, et al; HPTN 052 Study Team. Prevention of HIV-1 infection with early antiretroviral therapy. N Engl J Med. 2011;365(6):493-505.

7. Granich RM, Gilks F, Dye C, De Cock KM, Williams BG. Universal voluntary HIV testing with immediate antiretroviral therapy as a strategy for elimination of HIV transmission: A mathematical model. Lancet. 2009;373(9657):48-57.

8. Mocroft A, Lundgren JD, Sabin M, et al; Collaboration of Observational HIV Epidemiological Research Europe (COHERE) study in EuroCoord. Risk factors and outcomes for late presentation for HIV-positive persons in Europe: Results from the Collaboration of Observational HIV Epidemiological Research Europe Study (COHERE). PLOS Med. 2013;10(9):e1001510. doi:10.1371/journal.pmed.1001510

9. Raport $z$ analiz ankiet wypełnianych w Punktach Konsultacyjno-Diagnostycznych w roku 2010. Krajowe Centrum ds. AIDS, 2011. http://www.aids.gov.pl/badania_spoleczne/254/. Accessed January 15, 2017.

10. Rosińska M, Marzec-Bogusławska A, Janiec J, et al; for the CASCADE Collaboration in EuroCoord. HIV infection among HIV-positive individuals newly diagnosed at voluntary counseling and testing sites in Poland. AIDS Res Hum Retroviruses. 2013;29(5):805-813.
11. European Centre for Disease Prevention and Control and European Monitoring Centre for Drugs and Drug Addiction. Prevention and control of infectious diseases among people who inject drugs. Guidance in brief. Stockholm, Sweden: ECDC; 2011. http://www. emcdda.europa.eu/system/files/publications/638/ECDC-EMCDDA_ IDU_guidance_-_web_version_328027.pdf. Accessed March 24, 2017.

12. HIV-related stigma: Late testing, late treatment. A cross analysis of findings from the People Living with HIV Stigma Index in Estonia, Moldova, Poland, Turkey, and Ukraine. Global Network of People Living with HIV (GNP+), 2011. http://www.gnpplus.net/images/stories/Rights_and_ stigma/2011_HIVStigma_Report_EN.pdf. Accessed January 15, 2017.

13. Ankiersztejn-Bartczak M, Firląg-Burkacka E, Czeszko-Paprocka $\mathrm{H}_{\text {, }}$ et al. Factors responsible for incomplete linkage to care after HIV diagnosis: Preliminary results from the Test and Keep in Care (TAK) project. HIV Med. 2015;16(2):88-94.

14. Meulbroek M, Ditzel E, Saz J, et al. BCN Checkpoint, a communitybased centre for men who have sex with men in Barcelona, Catalonia, Spain, shows high efficiency in HIV detection and linkage to care. HIV Med. 2013;14(Suppl 3):25-28.

15. Desquilbet L, Deveau C, Goujard C, Hubert JB, Derouineau J, Meyer L; PRIMO Cohort Study Group. Increase in at-risk sexual behavior among HIV-1-infected patients followed in the French PRIMO cohort. AIDS. 2002;16(17):2329-2333.

16. Fisher JD, Fisher WA, Cornman DH, Amico RK, Bryan A, Friedland GH. Clinician-delivered intervention during routine clinical care reduces unprotected sexual behavior among HIV-infected patients. J Acquir Immune Defic Syndr. 2006;41(1):44-52.

17. Marks G, Crepaz N, Senterfitt JW, Janssen RS. Meta-analysis of highrisk sexual behavior in persons aware and unaware they are infected with HIV in the United States: Implications for HIV prevention programs. J Acquir Immune Defic Syndr. 2005;39(4):446-453.

18. Crepaz N, Lyles CM, Wolitski R, et al; HIV/AIDS Prevention Research Synthesis (PRS) Team. Do prevention interventions reduce HIV risk behaviors among people living with HIV? A meta-analytic review of controlled trials. AIDS. 2006;20(2):143-157. 